\title{
CRISIS OR EVOLUTION?
}

\section{Barnabás LENKOVICS ${ }^{1}$}

According to the author, the serious crisis of marriage and familyin the European(Western) civilization shall be stopped with effective legal protection and government measures. Since the root causes are complex, the protection shall also be the same. The natural and social side of man shall also be taken into account. The phenomenon of domination shall also be eliminated both within marriage and family. The level of the current legal protection cannot be reduced, it can only be increased. The priority (constitutional) protection of traditional marriage and family as natural and fundamental values is not discriminatory.

\begin{tabular}{l|l} 
marriage and family \\
crisis \\
evolution \\
protection and support \\
basic values \\
alternatives
\end{tabular}

\section{Crisis of marriage and family}

In his paper on the situation in Poland regarding the crisis of marriage and family, Professor Marek Andrzejewski mentioned the two concepts of crisis and evolution. The abovementioned paper was written within the framework of the 'Protection of family in the legal system' research project coordinated by the Ferenc Mádl Institute of Comparative Law. In addition to family law professors from Hungary and Poland, their peers from the Czech Republic, Slovakia, Serbia, Croatia, and Slovenia also took part in the research and prepared a so-called 'country report' for a comparative analysis. Are the symptoms and causes of the crisis the same, and how have the legal instruments for crisis management evolved from country to country? What common lessons can be drawn for the future? What are the most important similarities and possible differences between the crisis management practices of Western and Central European countries? Many other questions and answers can be explored from the country reports. I consider the most important, or fundamental, question to be the one posed in the title of this paper. This question is also

1 | Professor, Faculty of Law, Széchenyi István University of Győr, barnabas.lenkovics@gmail.com.

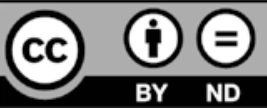


important from the viewpoint that many other answers depend on it; therefore, I believe that this question is worthy of a study in itself. Although, according to the rule of formal logic, the answer can be either crisis or evolution, with a compromise solution of 'crisis in some ways, and evolution in others', I give my own answer in advance: crisis.

In the countries that belong to the European (Western, Jewish-Christian) cultural circle, the crisis of marriage and family, in essence the lack of social reproduction, has reached a point where a red line must be drawn and it must be said so far and no further! Otherwise, these people will become extinct, its civilisational achievements will be destroyed, and its culture (including the culture of human rights) will fade into the mists of history. Since Europe is building a civilisation of 'freedom, justice, solidarity', and, according to the Christians, it is a civilisation of 'love and peace', the consequences of this crisis would be disastrous, with the effects limited to not just Europe. The changes that have led to this situation cannot be called evolutionary development or any development at all. The essence of evolution is not just change, but the acquisition or preservation of the ability to survive, and consequently the qualitative improvement to become a better human being. ${ }^{2}$ The process of becoming human may be complete in the biological sense, but the process of becoming a good human being, a better human being, and a more humane human being is not yet complete and can never be complete in the individual, national, civilisational, or global sense. The essential and primary condition for this evolution is the survival and reproduction of humans. However, the crisis of man, especially the crisis of the white human race, is at the root of the crisis of marriage and family, which in turn is at the root of the reproduction crisis. The crisis of man is in fact a crisis of values, or a crisis of the hierarchy of values. As an intended(?) or unintended(?) side effect, the 'value neutralisation' of society and the state has resulted in people with no value at the bottom of the value hierarchy, with their fundamental values questioned, destroyed, or existing only 'on paper'. This has become the fate of marriage and family, ${ }^{3}$ and with them loyalty, selfless love, respect, mutual solidarity and support, trust and gratitude, commitment, having children, being there for others, sacrifice, and so on. The crisis of marriage and family cannot be managed with the current thinking and attitudes about these values. Crisis management requires the preservation, rescue, and rehabilitation of the fundamental values. This is not impossible because many people share these values and set goals (e.g., happy marriage, big family), but later they are diverted by other goals and act contrary to their original goals, moving further and further away from them. This is a well-known paradox that can be resolved, even though it is not an easy task as the resolution of paradoxes is usually very difficult.

\section{A contradictory world}

Nowadays, young people postpone marriage or avoid it altogether, and, in many cases, they prefer the looser partnership type, cohabitation, over marriage. They do not have children,or have only one child. Furthermore, married couples divorce too easily, and their child is usually brought up without a father, etc. This is the typical marriage and

2 | Bregman, 2020, pp. 319-334.

3 | Fukuyama, 2000, pp. 31, 47, 59-60. 
family model. While this was not their original plan, the need to pursue their own careers and livelihoods, the need for freedom, travel, and pleasure, and so many other such values and goals push their marriage and family, and ultimately their lives, into the background and then into crisis. They look for happiness, but lose their way. ${ }^{4}$ They are not alone, and this is not the only wrong turn in today's world, the world of paradoxes.

The whole world is facing a population (human reproduction) problem. In the smaller but rich parts of the world, depopulation is causing increasingly serious problems (economic, social, and environmental), while in the larger but poorer parts, overpopulation is causing these problems. The two problems should be solved simultaneously, but separately. Global population migration-as it would contribute to overpopulation of the earth, where there are no more freely occupied territories-is not a solution, and it would only make the problem more serious.

The ecological footprint of humanity is growing every year, and the present generation is rapidly consuming (wasting, even destroying) the natural foundations, resources, choices, and opportunities of the future generations. The solution to the problem is not intentional depopulation. The World Inequality Report issued annually by Oxfam International shows that the super-rich people are rapidly growing in number and increasing their wealth while exploiting billions of people and nature and driving more than half of the world's population into poverty. Our world is morally, socially, and environmentally unsustainable. Production and consumption (unnecessary, superfluous, useless, and harmful), driven by compulsive growth, overburden the natural environment, accelerate climate change, cause increasingly severe climate disasters, endanger human life and the whole living world, and make hundreds of millions of people homeless, which is clearly unacceptable and unsustainable. These serious, paradoxical problems caused by man are unworthy of man as a rational and moral being, and violate the requirement of humanity and the right to human dignity. These problems do not receive the attention they deserve in science, politics, and international public life, and, therefore, are not prioritised in the daily lives of individuals. In contrast, other issues, such as sexual identity, receive disproportionate attention. Violent minority movements and organisations attack and destroy the traditional and natural institution of marriage and family, a crisis that is at the root of the population problem and which, of course, has deeper historical causes. These problems can only be solved if we try to manage them in their proper place, in proportion to their weight and importance. This requires a new way of thinking, because the crisis of marriage and family cannot be solved by the same thinking that caused or contributed to the problem in the first place.

\section{The complexity of the approach}

If an effect (negative social symptom) has more than one cause, they must first be examined individually and then in their totality including their interactions (to make the correct diagnosis); subsequently, the correct therapy can be considered-in a consultative manner with the involvement of several specialists and co-disciplines and combination of knowledge. 
Therefore, legal science should be opened up and its thinking base must be broadened so that it gains a social scientific and even a general scientific nature. ${ }^{5}$ It is true that we are talking about the need for an interdisciplinary approach to a complex, long-standing problem, but since jurisprudence is a closed system in itself, it tends to be constantly narrowing. It analyses its own concepts and examines them under a magnifying glass and then under a microscope until it becomes lost in its own problems. As an instrument of power, jurisprudence considers itself to be a big player in its own circle, but it is a pity that this circle is too small.

If, for example, marriage and family are in crisis, and we treat this only as a legal problem, although it is not primarily a legal problem, then solutions to this problem with any number of legal instruments will not be enough. All the essential causes of the problem should be identified and addressed appropriately. This must be managed in a holistic approach: if a person has multiple diseases and multiple causes, it is not enough to treat just one disease, cause, or symptom; the sickness must be treated as a whole (in its complexity).

If the crisis of marriage and family is understood as a symptom of disease of man and society, then the essential causes must be identified, investigated, and treated together. To heal the crisis of marriage and family, we can use the law as a means of regulating human behaviour. However, applying the human rights, family, or constitutional law research viewpoint and approaches alone is not enough; the 'consultation' and involvement of all 'human sciences' (natural and social sciences, including biology, human ethology, psychology, sociology, and economics) is needed.

\section{The natural side of man}

Man is a biopsychosocial being, ${ }^{6}$ a unity of physical, mental, and spiritual capabilities, in this evolutionary order. None of these aspects can be ignored, considered alone, or over-dimensioned. Marriage and family have an inborn natural side (original, genetic, physical and spiritual, biological): the instinct and motivating force of subsistence and procreation. For these purposes, a union of two people, that is, a monogamous relationship between a man and a woman, had developed within the ancient herd community. Survival and transmission of life are possible only when the couple is together and united; it is easier and healthier when the couple also forms a physical and spiritual unity. The pair then becomes parents and forms a family with their offspring.

The family was originally a consumption-oriented community leading a huntergatherer lifestyle with their main natural and moral law being that 'food must be shared'. Later, with the Neolithic revolution and paradigm shift, the family became the basic unit of farming with an emphasis on agriculture and settlement. Later, with the Neolithic revolution and paradigm shift, the family became the basic unit of farming with an emphasis on settlement and consequently marriage. Marriage and family, as living organisms, have their own natural evolutionary development, which is nothing but active adaptation to the changing natural and life-sustaining conditions. However, two closely related problems have arisen. One of the problems is that humans have domesticated not only plants

5 | Pokol, 2015, pp. 106-130.

6 | Kovács, 2007, p. 122.

7| Michel and Schaik, 2019, p. 62. 
and animals, but also themselves by not only experiencing, learning and mastering, and accumulating knowledge of the laws of nature, but also shaping and changing them to suit their own impulses. It is said that 'what a man thinks is mostly wrong, but what he knows is true'. ${ }^{8}$ The experienced laws of nature are permanent, and the conceived laws of man are fleeting. Although man is originally a natural being, while following his selfconceived laws, he is constantly distanced from nature and, in no small measure, even turned against it. As if he could create his own world, he begins to see himself as a god (homo deus?). ${ }^{9}$ Instead of protecting and caring for the nature that was entrusted to man by creation, mankind, which currently totals 7.5 billion, is not only using, but also destroying nature for the sake of its own world. His actions are unacceptable, unsustainable, and suicidal, both rationally and morally, according to common sense and moral (natural or divine) law as well. If a species, in this case man, exhausts its own resources, ruins its living conditions, and destroys whatever sustains its natural environment, it will also become extinct. Therefore, the natural side of man must also be carefully protected as part of nature conservation, and this is aided by the recently emerging evolutionary and complex scientific approach whose arrival is deliberate and not accidental.

\section{The social side of man}

The evolutionary development of marriage and family has a man-made social side in addition to the natural side; this side was created by man, adapting to changes in social circumstances (religions, ideologies, beliefs, political powers, farming methods, technologies, market laws, fashion, etc.). It can be said that they are purely human creations produced by humans according to their own interests, and always far fewer than those who are forced to adapt to them. If adaptation to social conditions is successful, regardless of whether it was voluntary, enthusiastic, or under pressure, these creations act as an unavoidable force (vis-maior) on the lives of individuals, just like the forces of nature. They can act as vitalising forces, as ideals and beliefs, objectives, and guides, or as experienced and proven fundamental values; on the other hand, they can also cause human and social disasters, as dogmas of mass-destructive ideologies. For example, the $20^{\text {th }}$ century was a disastrous century in this respect, dominated by man-made dogmas (e.g., fascist and communist). 'The power of dogma can be truly satanic only if it unites very large masses, whole continents, or even the mankind in a single evil misconception'.10 I think this kind of dogma is today's open society, which is nothing more than the created idea of a society falling apart, disintegrating into atoms due to total individual selfishness. Despite such rumours, man is a community being. Man is no longer a creation of an indigenous community, but still belongs to the community. He is a member of a family, a nation, a cultural community or civilisation (e.g., European), and the great family of humanity, or the human civilisation, and if he is sufficiently educated, he can strongly resist mass-destructive dogmas. As a valuable person who is rich in knowledge and in spirit, he is able to enrich his immediate and distant communities (e.g., his family, his nation, and humanity) and can resist the power of satanic dogma as well. 


\section{6 . The phenomenon of dominance}

Man has shifted from an existential mode of being to an existential mode of possession with the agricultural revolution, which is the greatest paradigm shift of humanity so far. ${ }^{11}$ According to the law, the essence of possession is the domination of things (goods) that are possessed and owned. The possessed goods constitute wealth. The exclusionary rights holder of all wealth is the owner.

The law recognised and protected the institution of private property against all outsiders. The essence of ownership rights as property status rights is full and exclusive legal power over property. However, the extent and value of possession and ownership can vary from one individual to another; consequently, the degree of dominance and power of each person can vary as well. This inequality has differentiated and later hierarchised property and the economic and political organisation of society. People without property or without sufficient property were placed in a dependent and vulnerable position to owners. Old win-win social games began to be displaced by new win-lose games. Property and the economic and social order built on it, and the hierarchical order of domination have always penetrated people's life relations, including the internal (intimate) relations of marriage and family. The agricultural revolution and settlement led to family farming and the establishment of private property. Private property and inheritance led to paternal power, which took over matriarchy. The emerging male domination, supported by private property power, was different in character from the previous female domination. Marriage also became a win-lose game. The industrial revolution abolished small private property, and the communist revolution abolished large private property, but the 10,000-year-old flywheel of male domination within the family continued to turn for two or three centuries. Today, the family has ceased to be the basic unit of economic management, but family households as a consumer community remain important in the consumer society. However, in this situation, there is no need for paternal or maternal power or male or female domination. In fact, now is the time for real equality between men and women, for free marriage based on strong attraction, for mutual loyalty and support, for starting a family with joint offspring, and for a renewed winner-takesall game.

\section{The liberation of man}

The intolerable legal and material (wealth) inequality has given rise to great ideas of equality throughout history (early Christianity, utopian socialism, scientific socialism, national socialism, communism). The mottos of civil enlightenment were 'liberty, equality, and fraternity'. The great codes of private law codified the emancipation of man (abolition of slavery, emancipation of serfs) and the social freedom of man (equality before the law, universal equality of rights, the principle of equality and co-ordination, horizontality), while transforming marriage and family relations as well. Movements and struggles were started for women's liberation, equality between 
women and men, and equality between spouses, in order to ensure freedom of marriage. Civil marriage became a contractual obligation between two parties, which can be freely contracted or dissolved. Legal relief had an incentive effect: the number of divorces began to rise, which had a negative effect on the number of marriages but encouraged the establishment of civil partnerships. Followers of a lasting and meaningful marriage, in the analogy of a 'sacramental' religious marriage, wanted more: a lifelong commitment, a life union, and a 'covenant marriage' with moral rights and obligations towards each other and the children. This excludes the ownership sense of the spouses, possession, or dominion over the other spouse, which is the most common cause of divorce. The equality experiment of socialism also failed because it practiced total domination based on state ownership when it should have eliminated the phenomenon of domination. The guarantee of real equality of rights of spouses in their relationship was characterised by the abolition of domination, effective equal sharing of the burden, and mutual support.

\section{The liberation of children}

The issue of liberation of children, which is also the liberation of the future generation, has shifted focus from paternal authority or parental domination to the protection of children's rights and unilateral parental obligations towards the child. The principle of the best interests of the child has been transformed from an international public law norm into a national principle of family law. However, a unilateral over-emphasis on children's rights, the severity of militant guardianship (e.g., against immigrant parents in some Scandinavian countries), or child tyranny are not in the interests of parents or the child. The 'single mother' model has become a social phenomenon and a legal concept. In many European countries and the USA, the majority of children are born out of wedlock or are placed with the mother in divorce and grow up without a father. The problem of the 'fatherless child' has emerged as a modern psychological syndrome, and, more generally, the problem of a 'fatherless society' ${ }^{12}$ is developing in the absence of paternal love.

The conditional, task-giving, performance-monitoring, strict, and disciplining, but always fair fatherly love is lacking, even though it is needed to balance the unconditional, forgiving, accepting, reassuring, and consoling love of mothers. Both forms of love are necessary for the child to grow into a mature adult with a sound mind. In other words, it is necessary for the child to learn that they have not only rights but also duties and responsibilities. Family law and judicial practice have realised this, which is why they no longer banish the divorced fathers from the family, but this does very little to address the social and psychological gravity of the problem. The lack of earned paternal and maternal prestige leads to a lack of respect for parents, which in turn leads to a lack of respect for marriage and family as fundamental values, which again leads to a general lack of prestige and respect and, thus, to a lack of respect for fundamental values, resulting in a general crisis of values. 


\section{The problem of legal reflection}

The question of the relationship between the economic basis and the social structure was one of the greatest debates of Marxist jurisprudence: does the economy determine the law or does the law determine the economy, and what transitional solutions can be imagined between the two extremes in time and space? The legal theory aspect of the question is the problem of the source of law: is the law built from below, evolving from social relations, or does it guide society from above as a state command, an instrument of political power? Is the state ruled by society, by the will of the people, or does the state rule society? I do not intend to answer these evergreen questions here and now, but I have raised them against the backdrop of the crisis of marriage and family as a toolbox for legal protection. The legal debates here are very similar. If the changes in marriage and family relations were an evolutionary developmental symptom, then the law would have no other task than to follow and reflect these changes. However, if the changes are a symptom of a crisis, they must be stopped and reversed, and the two institutions should be consciously protected and supported. Since the time of civil marriage, the natural and social evolution of marriage and family has been followed, mapped, and reflected in law, which has evolved and changed and continues to change. However, for nearly two thousand years before that time, marriage was dominated by canon law, which considered marriage as a sacrament and an indissoluble institution. In effect, it 'sanctioned' the effects (including the negative effects) of the agricultural revolution. In this respect, as we have seen, the paradigm shift was established by civil enlightenment, which promoted the ideas of 'liberty, equality, fraternity', and the institutionalisation of civil marriage, which considered marriage as a contract between two free people, one man and one woman, with equal rights, which could be dissolved as well. Initially, the principle of fault dominated the dissolution process, which turned it into a war between the parties, with the result that all parties became losers. This was followed by the principle of dissolution, which is more peaceful than the former as long as one party does not object to the divorce. The easiest, quickest, and cheapest way of dissolution is by an agreement of the parties, with two 'nos' for the marriage instead of two 'yeses'. In such cases of dissolution, there is no need for a church or a court, with the registrar sufficient in many countries. However, if a marriage was at first sacred and indissoluble, and then became a civil contractual bond, why should it be concluded at all as it is just a piece of paper! Thus, the alternative forms of cohabitation and partnership without marriage have begun to grow in popularity. Strangely, people living in such relationships have begun to claim the rights of spouses, albeit without the spousal obligations.

Because of political, sociological, and demographic facts and reasons, the law has constantly yielded to the growing social expectations, with the result that the manwoman partnership has been elevated to the status of marriage in terms of its essential elements. The concept of the so-called 'sociological family' has gained ground, with the prohibition of discrimination against children born out of wedlock playing a major role. The conscious and deliberate rejection of marriage and the resultant family and the choice of looser forms of partnership instead were not valued as legal facts. Cohabitation has been placed in a homogeneous group with marriage and family, whereas treating non-equals as equals can be discriminatory as well. On the other hand, it led to a further progressive erosion of traditional marriage and family as fundamental 
social and legal values. Moreover, legal generosity has not solved the crisis of marriage and family or the lack of social reproduction, but, as an unintended side effect, it has exacerbated these problems. The problem has been compounded by the growing number of alternative forms of relationships and cohabitation that have been claiming marriage and family status, especially for same-sex couples. In recent times, the global population migration and the reception of illegal migrants are contributing to this problem: superficially, as a replacement for a declining labour force, a little more profoundly, as a replacement for a decreasing population, and more profoundly and in the longer term, as a problem of 'population exchange' and even 'civilisation exchange'. Here again, we come to our initial question: is this the latest stage in the evolutionary development of marriage and family, or is the crisis already so deep that a remedy cannot be postponed? My answer is the same: because of the crisis of marriage and family, we have reached the red line of 'so far and no further' in legal regulation as well, which shall not be crossed.

\section{Social diversity}

The evolutionary development in nature, in the world of creatures, means that a species in danger becomes capable of adapting to changing natural conditions in order to survive. Replacing the endangered species with an alien ü, especially an 'invasive' species, is not survival or evolutionary development, but rather an acceleration of the extinction of the threatened species. In the case of humans, the issue is much more complicated; since 'all humans are brothers and sisters' in a global sense, all humanity is one big family. From the point of view of the threat of the climate catastrophe, the survival of the whole humanity in the 'natural' sense is also questionable. Moreover, in addition to natural conditions, man-made social conditions (cultural, religious, political, economic, and social) have also been substantially transformed, and among these, there may be shocks, collapses, and disasters to adapt to, or escape from. In addition to biodiversity, humans as a species are also characterised by social (cultural, religious, political, economic, social) diversity. The most serious issue of the global versus local debate is the preservation or elimination of this diversity, in the latter case, the homogenisation of the diversity and variety of the human species for the sake of survival. I acknowledge the importance of the principle of preservation. The preservation and maintenance of biodiversity is important for the conservation and maintenance of the natural foundations of life. The diversity and variety of our world is a source of beauty and an element of genetic richness, but it is also key to evolutionary progress. It provides choices for survival. This is also true for social diversity, which can not only be preserved, but also expanded and enriched in order to increase the chances of survival and the range of choices. Only one thing is forbidden, the use of violent means or methods by whatever name they are called such as war, 'democracy export', 'spreading of true faith', 'gender ideology', or 'sexual identity revolution'. The principles of freedom and responsibility, thus combined and interlinked, must also be applied in the field of marriage and family protection. 


\section{Our basic social values}

Marriage and family, freedom of marriage, equality between women and men, having children, and starting a family are no longer just natural, biological (genetic), and psychological values, but fundamental social values as well. They are universal human rights in the legal world and fundamental constitutional rights in national constitutions. They are valuable for human beings and therefore worthy of protection for the benefit of society and the state. The monogamous marriage of a woman and a man, based on mutual fidelity and support, and the family as a community built on love may be seen as fiction, ${ }^{13}$ but they are in fact attractive, stimulating, and value-enhancing objectives and fundamental values that improve human beings. They should be defended and protected from all valuedestroying, value-relativising ideas, movements, and activities. Marriage and family have a protective function for the physical and mental health of both women and men. This is particularly true for children whose best interest is to grow up in a harmonious family. Marriage and family, alongside faith, are the greatest sources of strength for surviving crises. They could also be resources for surviving the crisis of the two institutions. Family policy and legal protection, the family-friendly society, and the state should help in this endeavour.

\section{The non-derogation principle}

The principle of non-derogation ${ }^{14}$ was elaborated as a principle of environmental protection, especially nature protection, just half a century ago. This means that the achieved level of legal protection of nature cannot be reduced, but can only be increased. The protection of the natural foundations of life would protect the right to life of wildlife if it were a legal entity, and it would have a subjective or fundamental right. Because of the absence of these rights, the legislature prohibits man from destructive activities that destroy and endanger protected species of plants and animals and those that are under threat of extinction. Economic (investment) and social (job creation) policy objectives do not enjoy benefits over nature conservation. Economic growth, which damages or endangers nature, is no longer considered a development. The direction, pace, and scale of such development are unsustainable. The requirement of sustainability protects the right to life of wildlife, including the protection of human beings' right to life, which should be interpreted in conjunction with their right to dignity. If the natural basis of life is destroyed, the human being will perish along with it, which is the greatest violation of dignity, whereas human dignity is an inviolable fundamental right and value. It cannot be said that the principle of non-derogation is already fully applied in environmental and nature conservation practices, but at least it exists as a guiding principle in that area. What is the situation if a race of people is endangered? If the European white race is threatened with extinction, it should be declared as a protected species. Since the natural basis and traditional social framework for having children is marriage and family, or the union of a woman 
and a man (as a human and parent couple), this should be protected and encouraged by means of subsidies. The level of legal protection of marriage and family should achieve that level from where it cannot be reduced, but only increased. Any human behaviour, movement, or action that further destroys, violates, or endangers the natural and fundamental institution of marriage and family as a value that requires increased protection must be prohibited. Such ideologies, movements, and activities are unsustainable from the viewpoint of social reproduction. The ideas and actions of selfish individualism, which destroy society and family, are unacceptable. No human right can be interpreted in a way that would destroy, or even endanger, marriage and family.

\section{Purpose of rights}

The abuse of rights is a common problem of the too direct and concrete application of the general and too abstract norms of human rights. For example, emancipation of women should not go against the law of nature, that is, it should not be aimed at the total (biological) equalisation ${ }^{15}$ of the two sexes and the elimination of gender. There is no need for a permanent revolution or war against men ${ }^{16}$ in the women's movement, in which both parents and children and, indeed, the institution of marriage and family and social reproduction would be losers. The demand for the right of 'free' interoperability between the sexes, as well as its implicitly forced acceptance by the majority and its teaching to incapacitated children, is nothing other than a distorted interpretation of freedom of expression as unrestrained individualism.

This is similar to the idea of an open society, but this 'open to all - sexual - orientation' represents a disintegrating, mentally disturbed, drifting personality. It is an evolutionary deception, or as Pope Francis called it an 'anthropological impasse'. Freedom is not boundless and unlimited; it is forbidden to abuse it at the expense of others. The freedom of an individual is freedom within the family and society, and not freedom from the family and society. Solidarity (which also means marital, family, and social solidarity) is the freedom for the family and society from the viewpoint of Christian benevolence. ${ }^{17}$ Man needs faith and experiential knowledge that keeps him and his personality on the right path.

Just as the basic freedom and human rights of adult men and women are not purposeless and unlimited, the rights of children are also not unlimited and unbound. Nor can a child treat the parent in an inhuman way and humiliate, torture, or enslave them. The table has turned and it is time to free parents from the 'child rule', otherwise no one will have children at all. Thus, there are no unlimited rights, just as there is no unlimited power. The source of rights is the fulfilment of obligations: the obligation of husband towards the wife and vice versa, parent to child, child to parent, etc. According to this view, the freedom of the individual and the personality of man, thereby humanity, which is usually represented as concentric circles, can only unfold and be fulfilled in the communities. As Article 29(1) of the UN's Universal Declaration of Human Rights (UDHR) stipulates, '[e]veryone has duties to the community in which alone the free and full development of his personality is possible'. Thus, it is not the egocentric vision of man

15 | Pokol, 2011, pp. 188-195.

16 | Murray, 2020, pp.136-143.

17 | Zlinszky, 2007, p. 20. 
and society that prevails, but the original, traditional, community, and sociocentric vision of man and society. According to this view, a person's worth is measured by what he is, and not what he has. We do not live to have more, but to be more, ${ }^{18}$ and thereby to enrich others in terms of values, spirit, knowledge, and integrity.

\section{The value of monogamy}

Man was originally of polygamous inclination (traces of which are noticeable even today), but in the evolutionary process over hundreds of thousands of years, man has become monogamous, or at least adopted it by exercising the virtues of prudence and temperance. If we consider the question of polygamy or monogamy from an evolutionary perspective over a long period of time, it can be seen that it is not a recent one, with its roots going back to prehistoric times. We know little about these times, and a wide range of conclusions can be drawn from archaeological records, which can be neither proved nor disproved. Consequently, our thoughts and statements are presumptions, which are well known in law, i.e., probabilities, which we consider to be real. To confirm our presumptions, we usually reflect on the past based on empirical knowledge of later times, which may also carry doubts. Nevertheless, the gravity of the problem (the crisis of heterosexual, monogamous marriage and family that is built on it, plus its exposure to increasing attacks) and its continuing aggravation force us to reflect on the issue to see if any thought can bring us closer to the problem and help us find the right solution. In the sciences, the assumptions, intuitions, and imagination of scientists often play a major role. They see what everyone else can see, but at the same time think about such things in a way that others cannot. For more than two million years, prehistoric and Neanderthal men lived as community creatures: in a community of women and men, in a community of children and property, and in and as part of nature. Mutual cooperation ensured the vitality, survival, and evolutionary development of the community. This situation presumes win-win games in relations within the community. Man's original natural inclination was polygamy, and monogamy was considered a deviant behaviour. The sexual attraction (dominance) of women and the linking of children to their mothers resulted in a matrilineal society and, female domination (matriarchy) within it. This female domination did not threaten but rather strengthened community cooperation and resulted in win-win games. However, as a result of biological developments over a long period of time, the monogamous male-female pair relations developed and became the rule. There are many reasons for this, of which at least three can be highlighted as being highly probable. The first is that, in addition to, and sometimes instead of, the casual and instinctive sexual relationships, more enduring sympathetic relationships developed, driven by strong mutual attraction and permanent bonds (today we can say that the chemistry of love' developed and operated between some couples). Second, in such relationships, the presumption of paternity was narrowed to the permanent male partner, who became more devoted to the care of his own child and the mother, his wife (even at the expense of his own maintenance, as the family law-as a natural law-still requires both parents to do today). The third reason, as mentioned by Professor Nizsalovszky in his book from 
$1963,{ }^{19}$ was that in the case of children born from a relationship with two identifiable parents, incest and the risk of giving birth to genetically defective offspring could be excluded. Other reasons and causes of monogamy may have included mutual sexual loyalty, increased support for each other, and mutual trust, which spilled over to other monogamous couples in the community and to the whole community. Consequently, it reinforced the sense of belonging, mutual cooperation, and community solidarity, eventually contributing to the win-win game.

It is interesting that Plato, in Book III of his work State, believed that 'the taking of wives, marriage and the procreation of children should be made public property', and in Book V, he proposed a so-called 'community of women and children' in the order of guards to 'prevent discord'. Arguing with his master, Aristotle wrote in Politics that

they care at least for that which has the most masters: everyone cares most of his own, and less for the common, or only so far as he is concerned, and because they think that he is cared for by someone else, they prefer to forget him [...] For there are two essential conditions in men which testify to care and love: property and affection; only neither of these can be found in such citizens. ${ }^{20}$

This empirical knowledge was confirmed by the failure of the historical experiment of communism, or by the dissolution of the hippie communes in the second half of the $20^{\text {th }}$ century. Therefore, monogamy originally emerged as a win-win couple relationship, the result of the natural evolutionary development of man, even before the advent of private property and the agricultural revolution. It was not only an institution and means for joint procreation by a man and woman, but also a tool for the survival of the social community. It was also a vehicle of values that served to improve man and community. Article 16(3) of the UN UDHR acknowledges that '[t]he family is the natural and fundamental group unit of society and is entitled to protection by society and the State'. It is also clear when reading paragraphs (1) and (2) that we are talking essentially about a monogamous marriage between a man and a woman, and a family complete with children. The UN UDHR is a universal norm that encapsulates the fundamental values of mankind, which are protected by Articles 29 and 30 against any abuse.

\section{Are there any alternatives?}

According to my personal point of view, there is no equal alternative to monogamous marriage between a man and woman, and family with children. However, the facts that there are alternative forms of partnership and cohabitation, and that the concept of having children has also been broadened by the possibilities of adoption, fostering, and human reproduction procedures cannot be ignored. The spread of alternative forms of relationships is a way out of the crisis of marriage and family. However, since the fault lies not in marriage and family, but in the person who marries and has a family, alternative forms of relationships also exhibit the same symptoms of crisis as 
marriage and family. If a marriage breaks down, the parties behave like consumers in a consumerist society: they do not fix it but throw it away and buy another. This is an unacceptable waste.

A person, even a bad spouse, is more valuable than any thing. Even if they are incorrigible, they cannot be thrown away, especially if they have a child together. The situation is similar for alternative relationships like cohabitation; they can also carry important values from the viewpoint of society and can be legally protected and (despite the differences) supported. Encouraging and rewarding a more serious and responsible marriage will not result in discrimination and cannot be classified as homophobia. The essence is in the legal recognition of the differences in the chosen life situations, and in the legal distancing between the different forms of relationships. The legal representation of an original difference (otherness) is not discrimination; on the contrary, treating those who are different as identical can be considered discriminative.

\section{Summary}

Marriage and family are essential for social reproduction; they are traditional, wellestablished means of population replacement in ageing and declining societies, as well as overpopulated ones, and, therefore, need to be strengthened, rehabilitated, rebuilt, and better protected. The mass admission of illegal migrants from foreign civilisations will not result in population replacement, but in population exchange, and ultimately civilisation exchange. Unsurprisingly, that population would be the winner, which appreciates marriage, family, having children, fatherhood, and motherhood. This would lead to the decline and fall of a great European, Western, or Christian civilisation, leading to the 'strange death of Europe'. ${ }^{21}$ Those who repair and save their marriage and family can repair and save their nation and Europe as well.

What needs saving is not only marriage and family, or the population and culture of Europe, but also the soul of Europe and European man. 'All European states have been shaped by Christian civilisation. It is precisely this European soul that shall be resurrected', according to Robert Schuman. ${ }^{22}$ According to Popes Paul VI and John Paul II, Europe is building a civilisation of love. ${ }^{23}$ The European Union acknowledges the principles of freedom, justice, and solidarity. Solidarity is called benevolence by Christians. Europe is a forerunner of universal (global) solidarity, which is a model and guide for humanity. Solidarity starts with win-win games in the family and radiates to national, European, and global levels. Global capital and the domination of the global financial market are not at the heart of globalisation, profit maximisation, and utilitarianism, which should not be the main guiding ideals. There is no need for a war of nations or a clash of civilisations. Instead of racism and chauvinism, we must talk about culturalism, as national cultures enrich the diversity of our world. We also need familism rather than militant feminism, genderism, sexual revolutionism, and the war of the sexes. ${ }^{24}$ The common essence of

21 | Murray, 2018, pp. 5-11.

22 | Lejeune, 2015, p. 249.

23 | Vereb, 2010, pp. 174 and 194.

24 | Kopp and Skrabski, 2020, p. 66. 
family is the community of love, i.e., a community that holds its members together and keeps them united. Becoming a human being begins at birth, but a person's humanity and personality are formed in the family, a community of love, and then continues in their marriage and family. This is an unbroken chain of generations, a circular development on an ever-higher level, which can never end and can never be completed. It is a miracle and a gift of life, participation in which can contribute personally to the preservation and development of marriage and family. 


\section{Bibliography}

| Arisztotelész (1984) Politika. Budapest: Gondolat Kiadó.

Bregman, R. (2020): Emberiség - Mégis jobbak lennénk, mint hittük? Budapest: HVG Könyvek.

| Elemér, H. (2014) Az emberi kaland. Budapest: Helikon Kiadó.

| Fromm, E. (1994a) Birtokolni vagy létezni? Budapest: Akadémiai Kiadó.

| Fromm, E. (1994b) A szeretet müvészete. Budapest: Háttér Kiadó.

| Fukuyama, F. (2000) A Nagy Szétbomlás. Budapest: Európa Könyvkiadó.

| Harari, Y. N. (2020) Homo Deus - A holnap rövid története. Budapest: Animus Kiadó.

| József, K. (2007) Bioetikai kérdések a pszichiátriában és a pszichoterápiában. Budapest: Medicina Kiadó.

Kopp, M., Skrabski, Á. (2020) A boldogságkeresés útjai és útvesztői. Budapest: KINCS - L'Harmattan.

Lejeune, R. (2015) Politika és életszentség - Robert Schuman, Európa atyja. Budapest: Magyar Máltai Szeretetszolgálat,.

| Lorenz, K. (1988) A civilizált emberiség nyolc halálos büne. Sopron: IKVA Könyvkiadó.

Michel, K., Schaik, C. V. (2019) Az ember három természete - A Biblia evolucionista olvasata. Budapest: Typotex Kiadó.

| Murray, D. (2018) Európa furcsa halála. Budapest: Alexandra Kiadó.

| Murray, D. (2020) A tömegek tébolya. Budapest: Alexandra Kiadó.

Pokol, B. (2011) Európa végnapjai - A demográfiai összeroppanás következményei. Budapest: Kairosz Kiadó.

Pokol, B. (2015) ‘A jogtudomány társadalomtudományosítása (és így perspektivikus létrejötte)', Jogelméleti Szemle, 2015/2.

| Ranschburg, J. (2011) Érzelmek iskolája. Budapest: Saxum Kiadó.

| Vereb, J. (2010) Minden napra egy gondolat (II. János Pál). Budapest: JLX Kiadó.

Zlinszky, J. (2007) Közéleti és jogászi etika a gyakorlatban. Budapest: Szt. István Társulat. 